\title{
Performance and Meat Quality of Growing Pigs Fed Composite Leaf Meal Premix as an Alternative to Commercial Premix
}

\author{
Adegbenro, Muyiwa; Agbede, Johnson Oluwasola; Onibi, Gbenga Emmanuel; Aletor, \\ Valentine Ayobore
}

Department of Animal Production \& Health, The Federal University of Technology, Akure, Nigeria.

\begin{abstract}
Corresponding Author: Adegbenro, M. Department of Animal Production and Health, The Federal University of Technology, Akure, Nigeria. Email: madegbenro@ futa.edu.ng Phone:+234 8034935735
\end{abstract}

\begin{abstract}
This trial was designed to study the effects of using composite leaf meal produced from five (5) different leaves: Cassava, Moringa, fluted pumpkin, African basil and bitter leaves as a premix in the diets of growing pigs. Twenty four large white weaner-pigs were used for this trial comprising six treatments and four replicates with one pig per replicate. Six diets were formulated in which composite leaf meal was fed at 0 (2.5\% premix), $10(2.0 \%$ premix), 20 (1.5\% premix), 30 (1.0\% premix), 40 (0.5\% premix) and 50 (0.0\% premix) $\mathrm{g} / \mathrm{kg}$ at the expense of a commercial premix and designated diets I, II, III, IV, V and VI. The pigs were then assigned to these 6 dietary treatments which were fed to the pigs at $5 \%$ of their body weight for 8 weeks experimental period. Water was supplied ad libitum throughout the experimental period. All data were subjected to analysis of variance. Results showed that, there was no significant difference $(P>0.05)$ in the final weights of the pigs. Highest final live weight $(41.67 \pm 0.84 \mathrm{~kg})$ and highest feed intake $(75.92 \pm 0.06)$ were recorded in animals fed diet II, while the lowest final live weight $(37.67 \pm 0.84 \mathrm{~kg})$ and lowest feed intake $(75.57 \pm 0.06)$ were recorded in animals fed diets $V$ and $I$, respectively. The eye muscle width of carcass was significantly higher $(P<0.05)$ in pigs fed composite leaf meal diets than those fed the control. The eviscerated weights $(\mathrm{kg})$, head $(\mathrm{kg})$, carcass length $(\mathrm{cm})$ and the relative organs weight of liver, kidney, heart, lungs and spleen $(\mathrm{g} / \mathrm{kg}$ body weight) were not significantly $(P>0.05)$ influenced by the dietary treatments. The longest carcass length was recorded in animals fed diet VI $(73.00 \mathrm{~cm})$, while the shortest length was recorded in animals fed diet III $(69.33 \mathrm{~cm})$. For the $\mathrm{pH}$ of the meat samples, the highest value (5.77) was recorded in pigs fed diet VI, while the lowest $\mathrm{pH}$ (5.74) was recorded in pigs fed diet $I$. However, there was no significant $(P>0.05)$ treatment effect in the $p H$ values. Generally, the cost of the experimental diets ( $/ \mathrm{kg}$ ) was least in $50 \mathrm{~g} / \mathrm{kg}$ composite
\end{abstract}

leaf meal diet ( $\$ 55.44 / \mathrm{kg}$ ) and highest in $0 \mathrm{~g} / \mathrm{kg}$ composite leaf meal diet ( $\$ 60.43 / \mathrm{kg}$ ) and the percentage cost reduction increased as the level of the composite leaf meal inclusion increased $(1.44-8.26 \%)$. It could be concluded within the limit of this study, that composite leaf meal had high nutrient potentials for pigs and could completely replace commercial premix in pig diets without any deleterious effect.

Keywords- Pig production, Composite leaf meal, Premix, Growth, Carcass characteristics, Relative organs weight, Meat pH, Eye muscle.

\section{INTRODUCTION}

The search for least-cost rations has led to the replacement of expensive feeding-stuff with cheaper alternatives like agricultural by-products and leaf meal in the formulation of pig rations. The increasing competition between man and animals for available grains is one of the factors causing protein intake shortages in developing nations like Nigeria. The resultant sub-optimal consumption of animal protein by a greater percentage of Nigerian population has challenged not only livestock farmers, but also researchers and policy makers (Iheukwumere et al., 2007). The realization that feeding alone currently accounts for over $75 \%$ of intensive nonruminant (poultry and pig) production in the third world countries, including Nigeria has stimulated research interest aimed at exploiting different locally available alternative feeding resources (Agbede and Aletor, 2003). The need to harness the potentials of the numerous agroindustrial by-products and green vegetable plants as replacements for the more expensive conventional feed ingredients have been variously expressed (Agbede and Aletor 2004; Adegbenro et al., 2012). Leaf meals not only serve as a protein source but also provide some necessary vitamins such as vitamin $\mathrm{A}$ and $\mathrm{C}$, minerals and also oxycarotenoids, which causes yellow colour of broiler 
skin, shank and egg yolk (Abu et al., 2015). Considerable attention has been focused on leaf meals from Cajanus cajan (Damaris, 2007). This study is therefore seeks to evaluate the effect of feeding varying levels of composite leaf meal as a replacement for premix on the performance, carcass and organ characteristics of growing pigs.

\section{MATERIALS AND METHODS}

Composite Leaf Meal Production: Leaves from five (5) selected plants (Cassava, Moringa, Fluted pumpkin, African basil and Bitter leaves) were "harvest" and airdried to prevent loss of some vital nutrients. The air-dried leaves were milled using hammer mill and stored in plastic containers prior to use. Thereafter, the leaves were mixed together in the same ratio $(1: 1: 1: 1: 1)$ to produce the composite leaf meal.

Experimental Diets and Site: A basal diet was formulated to meet the requirement of swine (NRC, 1994). The quantity of the commercial premix in the basal diet (Diet I) was reduced by 0, 20, 40, 60, 80 and $100 \%$ replaced with $0,10,20,30,40$ and $50 \mathrm{~g} / \mathrm{kg}$ of composite leaf meal designated Diets I - VI, respectively as presented in Tables 1 and 2. The feeding trial was carried out at the Livestock Section (Piggery Unit) of the Teaching and Research Farm of The Federal University of Technology, Akure, Nigeria.

Experimental Animals and Management: The statistical design of the experiment was a completely randomized design with a total number of twenty four (24) weanling pigs (Suis large white) assigned to six (6) dietary treatments, replicated four times with one (1) pig per replicate. The weight of each pig was measured and recorded as initial weight for the animal. Each animal's weight was recorded and later balanced in order to get the average weight for all the treatments. Thereafter, their respective weaners' diets were fed at $5 \%$ of their body weight for the period of four weeks during which the weekly feed consumption and weight changes were measured and feed conversion ratio were calculated. Thereafter, the growers diets were fed to their respective group from the fifth week to the eight weeks at $5 \%$ of their body weight and the same parameters at the weaners' phase were measured.

Slaughtering of Animals: At the end of the feeding trials, all the animals were starved over night and weighed. The animals were hanged suspended upside down on their hind limbs so as to allow for proper bleeding. The animals were then sacrificed through mechanical stunning severance of the jugular vein. Each slaughtered animal was de-haired using cold water, soap and blade and dressed. The animal's lengths were measured after which they were eviscerated and dissected into parts. The following weights were taken; live weight $(\mathrm{kg})$, dressed weight $(\mathrm{kg})$, eviscerated weight $(\mathrm{kg})$, head $(\mathrm{kg})$, liver $(\mathrm{g} / \mathrm{kg})$, heart $(\mathrm{g} / \mathrm{kg})$, kidney $(\mathrm{g} / \mathrm{kg})$, lungs $(\mathrm{g} / \mathrm{kg})$ and spleen $(\mathrm{g} / \mathrm{kg})$. Also, the following measurements were taken; carcass length $(\mathrm{cm})$, eye muscle $(\mathrm{cm})$, subcutaneous shoulder fat $(\mathrm{cm})$, loin $(\mathrm{cm})$, fat over mid back $(\mathrm{cm})$ and loin side $(\mathrm{cm})$. The head was removed and carcass split longitudinally down the mid line. The length was measured from the anterior edge of the symphysis pubis to the recess of the first rib. Subcutaneous fat depths were measured on each side over the shoulder, mid back and loin. Sides from each carcass were cut across at a point level with the head of the last rib. The maximum width (A) and depth (B) of the exposed M. longissimus were measured. The thickness of the subcutaneous fat surrounding the $M$. longissimus was measured at sites $\mathrm{P}_{2}$ (65 $\mathrm{mm}$ from the dorsal mid line), $\mathrm{C}$ (over B at right angle to the skin) and $\mathrm{K}$ (at the dorso-lateral corner of the $M$. longissimus and at a right angle to the skin) (Gill et al., 1995). The $\mathrm{pH}$ of the meat muscles samples was determined using a digital $\mathrm{pH}$ meter (DpH-2 ATAGO $\left.{ }^{\circledR}\right)$. A sharp pointed knife was used to pierce the intact muscles to about $3-4 \mathrm{~cm}$ and the digital $\mathrm{pH}$ meter was immediately inserted into the sample muscles to read the $\mathrm{pH}$. The cost of producing the experimental diets were estimated based on prevailing market prices for the ingredients as at the time of the experiment and percentage cost reduction was evaluated.

Statistical Analyses: Data collected were subjected to one-way analysis of variance using SPSS version 13 package and where significant differences are found; the means were compared using Duncan Multiple Range Test of the same package.

\section{RESULTS}

Performance and Cost of Production Estimate: The influence of composite leaf meal on the performance of swine indicated that there were no significant differences $(\mathrm{P}>0.05)$ in final live weight and total feed intake among the treatments as presented in Table 3. Highest final live mean weight $(41.67 \pm 0.84 \mathrm{~kg})$ and highest mean feed intake $(75.92 \pm 0.06)$ were recorded in animals fed $10 \mathrm{~g} / \mathrm{kg}$ composite leaf meal, while lowest final live mean weight $(37.67 \pm 0.84 \mathrm{~kg})$ and lowest mean feed intake $(75.57 \pm$ $0.06 \mathrm{~kg}$ ) were observed in animals fed $40 \mathrm{~g} / \mathrm{kg}$ and $0 \mathrm{~g} / \mathrm{kg}$ composite leaf meal, respectively. The weight gain and the feed conversion ratio of the experimental animals were significantly influenced $(\mathrm{P}<0.05)$ by the dietary treatments. Highest mean weight gain $(23.67 \pm 0.51 \mathrm{~kg})$ was recorded in animals fed $10 \mathrm{~g} / \mathrm{kg}$ composite leaf meal, 
while the lowest mean weight gain $(19.33 \pm 0.51 \mathrm{~kg})$ was observed in animals fed $40 \mathrm{~g} / \mathrm{kg}$ composite leaf meal. For the feed conversion ratio, the highest mean value $(3.95 \pm$ 0.09 ) was observed in animals fed $40 \mathrm{~g} / \mathrm{kg}$ composite leaf meal and lowest mean value $(3.22 \pm 0.09)$ was observed in animals fed $10 \mathrm{~g} / \mathrm{kg}$ composite leaf meal. Generally, the cost of experimental diets $(\mathrm{N} / \mathrm{kg}$ ) was least in $50 \mathrm{~g} / \mathrm{kg}$ composite leaf meal diet ( $\$ 55.44 / \mathrm{kg}$ ) and highest in 0 $\mathrm{g} / \mathrm{kg}$ composite leaf meal diet ( $\$ 60.43 / \mathrm{kg}$ ) and the percentage cost reduction increased as the level of the composite leaf meal inclusion increased $(1.44-8.26 \%)$.

Carcass and Organs Characteristics: The results from the carcass and organ evaluation of swine fed composite leaf meal diets indicated that there were no significant differences $(\mathrm{P}>0.05)$ in all the parameters measured as shown in Table 4. The eviscerated weights, head weight, carcass length and the relative organs weight of liver, kidney, heart, lungs and spleen were not significantly influenced $(\mathrm{P}>0.05)$ by the dietary treatments. Highest eviscerated weight $(38.33 \mathrm{~kg})$ was observed in animal fed diet VI $(50 \mathrm{~g} / \mathrm{kg}$ composite leaf meal) while the lowest value $(36.00 \mathrm{~kg})$ was observed in animal fed diet III $(20 \mathrm{~g} / \mathrm{kg}$ composite leaf meal). Animals fed diet VI (50g/kg composite leaf meal) had the highest value for head $(3.95 \mathrm{~kg})$ while animals fed diet V $(40 \mathrm{~g} / \mathrm{kg}$ composite leaf meal) had the lowest value $(3.65 \mathrm{~kg})$. The result on eviscerated weight was not significantly different among the treatment mean values but numerically higher in animals fed diet VI $(50 \mathrm{~g} / \mathrm{kg}$ composite leaf meal). Animals fed Diet II (10g/kg composite leaf meal) had the highest live weight per animal $(41.67 \mathrm{~kg})$. The longest carcass length was recorded in animals fed $50 \mathrm{~g} / \mathrm{kg}$ composite leaf meal $(73.00 \mathrm{~cm})$ while the shortest carcass length was recorded in animals fed diet $20 \mathrm{~g} / \mathrm{kg}$ composite leaf meal $(69.33 \mathrm{~cm})$. Animals fed diet $50 \mathrm{~g} / \mathrm{kg}$ composite leaf meal had the highest liver value $(956 \mathrm{~g} / \mathrm{kg})$ while animals on diet $0 \mathrm{~g} / \mathrm{kg}$ composite leaf meal had the lowest value $(779.33 \mathrm{~g} / \mathrm{kg})$. The kidney of animals fed diet II $(10 \mathrm{~g} / \mathrm{kg}$ composite leaf meal) had the highest value $(133.67 \mathrm{~g} / \mathrm{kg})$ while lowest value was recorded in animals fed diet $20 \mathrm{~g} / \mathrm{kg}$ composite leaf meal (114.67 g/kg). Animals on diet I $(0 \mathrm{~g} / \mathrm{kg}$ composite leaf meal $)$ had the highest value for heart $(153.67 \mathrm{~g} / \mathrm{kg})$ while lowest value was observed in diet $30 \mathrm{~g} / \mathrm{kg}$ composite leaf meal (123 $\mathrm{g} / \mathrm{kg}$ ).

\section{Eye Muscle Measurement, Fat Deposition and pH:}

The influence of composite leaf meal on the eye muscle, fat deposition and $\mathrm{pH}$ of the experimental animals indicated that the eye muscle width and midback fat were significantly influenced $(\mathrm{P}<0.05)$ by the dietary treatments as presented in Table 5. However, the eye muscle depths, shoulder fat, loin fat and C, K, P were not affected by the dietary treatments. Highest eye muscle width and depth were recorded in animals fed $10 \mathrm{~g} / \mathrm{kg}$ composite leaf meal ( 7.48 and $3.35 \mathrm{~cm}$, respectively). The lowest eye muscle width and depth were recorded in animals fed $0 \mathrm{~g} / \mathrm{kg}$ composite leaf meal $(6.87$ and $3.03 \mathrm{~cm}$, respectively). The lowest sub fat loin was recorded in animals fed $20 \mathrm{~g} / \mathrm{kg}$ composite leaf meal $(0.72 \mathrm{~cm})$, while highest was recorded in animals fed $10 \mathrm{~g} / \mathrm{kg}$ composite leaf meal $(1.25 \mathrm{~cm})$. For $\mathrm{C}, \mathrm{K}$, and $\mathrm{P}$; highest values were recorded in $10 \mathrm{~g} / \mathrm{kg}$ composite leaf meal (1.02, 1.28 and $1.08 \mathrm{~cm}$, respectively). Lowest $\mathrm{C}, \mathrm{K}, \mathrm{P}$ values were recorded in animals fed $30 \mathrm{~g} / \mathrm{kg}$ composite leaf meal and $40 \mathrm{~g} / \mathrm{kg}$ composite leaf meal $(0.72,0.63$ and $0.60 \mathrm{~cm}$, respectively). For the $\mathrm{pH}$ of the meat samples, highest value $(5.77 \mathrm{pH})$ was recorded in animals fed $50 \mathrm{~g} / \mathrm{kg}$ composite leaf meal while lowest value $(5.74 \mathrm{pH})$ was recorded in animals fed $0 \mathrm{~g} / \mathrm{kg}$ composite leaf meal. However, there was no significant $(\mathrm{P}>0.05)$ difference in the $\mathrm{pH}$ values.

\section{DISCUSSION}

All pigs were in apparently good health during this trial. Feed conversion ratio (FCR) was statistically similar in all dietary treatments. The best FCR was recorded in animals fed $10 \mathrm{~g} / \mathrm{kg}$ composite leaf meal diet, which indicated that animals utilized their feed better than those fed other test diets at this stage. Similar final weight, weight gain and feed conversion ratio across treatments suggested that commercial premix could be replaced completely with composite leaf meal without any serious adverse effect on the growth parameters (Adegbenro et al., 2012). In general, the growth parameters measured in animals fed the control diet and those fed the composite leaf meal diets were identical, thus suggesting the nutritional adequacy of the composite leaf meal in replacing the commercial premix in pig diet in sub-tropical Africa where these leaves are abundant. Thus, in the course of world clamour for sustained food security through enhancement of organic farming, the combination of these leaves could be used as a cheaper replacement of commercial premix in swine diets. The economy of production revealed that the cost of feed per kilogram of feed and cost of feed per gain were affected by the dietary treatments. These cost indicators were highest in the control diet and lowest in the $50 \mathrm{~g} / \mathrm{kg}$ composite leaf meal diet, which suggests plausible economic benefit of this inclusion level in pig production. As a result of an increase in percentage cost reduction as the level of the composite leaf meal inclusion increased, it may be safe to completely replace commercial premix with composite leaf meal as this would result in lower the cost of production, increased meat production and affordability 
by the resource poor. For instance, the complete replacements of commercial premix with composite leaf meal at 5\% inclusion level reduced about \$8.26 per kilogram of feed. This translates to a colossal savings of $\$ 82,600$ per tonne by farmers (Adegbenro et al., 2012). This observation could encourage pig farmers to produce more and thereby making meat available for the populace. Carcass has been shown to be an instrument that determines the relationship between the "whole sale" or "retail cuts" of animals. Observation on the eviscerated weight therefore implies that th $\mathrm{e}$ of animals may not necessarily be directly proportional to the performance traits. The result on carcass length indicates that the diets promoted the development of identical carcass length percent. Organs are body parts, composed of several types of tissues, capable of carrying out specialized function (Sarojini, 2005). Among the organs measured are; liver, kidney, heart, lungs and spleen. The organs weight measured in this study were not influenced by the treatments, thus suggesting that the diets were not detrimental. The eye muscle width and eye muscle depth increased with increased live body weight of pigs which indicate that pigs with lighter body weight will possess smaller eye muscle width and eye muscle depth (Gill et al., 1995). Shoulder fat, midback fat and loin fat reduces as the level of the composite leaf meal increases but does not follow any particular trend. This could be linked to the fact that composite leaf meal contains some elements that helps in reducing lipogenesis in the animals. The low $\mathrm{pH}$ obtained makes the meat better in terms of appearance and keeping quality. The $\mathrm{pH}$ of meat is an important for determining its quality characteristics. Anaerobic glycolysis generates lactate that accumulates, lowering the intracellular $\mathrm{pH}$ of meat, so that by 24 hours post mortem the $\mathrm{pH}$ has fallen to an ultimate $\mathrm{pH}$ of about $5.4-$ 5.7 (Chalotte et al., 2003). The ultimate $\mathrm{pH}$ depends on glycogen concentration at the time of slaughter (Przybylski et al., 2006). From the current work, the $\mathrm{pH}$ values ranged from $5.74-5.77$ which is still in range of the report of Chalotte et al. (2003) and the values of $5.3-$ 6.9 reported for pigs by FDA (2012).

Conclusion: The quality of meat depends on numerous factors. The attention is most often focused on the effect on nutrition on meat quality such as $\mathrm{pH}$ value, fat quality etc. This research has shown that composite leaf meal will not cause any deleterious effects on the quality of meat produced from these pigs considering the fat quality and $\mathrm{pH}$ level. Also, inclusion of composite leaf meal reduced the cost of experimental diets which could help to stem over dependence of pig farmers on importation of conventional premix in developing countries like Nigeria.

\section{ACKNOWLEDGEMENT}

The authors are grateful to STEP - B, Federal University of Technology, Akure for Innovators of Tomorrow (IOT) grant award to Adegbenro Muyiwa with which this study was conducted.

\section{REFERENCES}

[1] ABU, O. A., OlalerU, I. F., OKE, T. D., ADEPEGBA, V. A. and USMAN, B. (2015). Performance of broiler chicken fed diets containing cassava peel and leaf meals as replacements for maize and soya bean meal. International Journal of Science and Technology, Volume 4, No 4.

[2] ADEGBENRO, M., AYENI, A. O., OLOWOYEYE, J., BANKOLE, O. M., AGBEDE, J. O., ONIBI, G. E. and ALETOR, V. A. (2012). Leaf composite mix as alternative premix to commercial premix in broiler finisher diets. Tropentag 2012, Resilience of System against Crises, Book of Abstracts, Pp 71

[3] AGBedE, J. O. and ALETOR, V. A. (2003). Evaluation of fish meal replaced with leaf protein concentrate from glyricidia in diets for broilerchicks: Effect on performance, muscle growth, haematology and serum metabolites. International Journal of Poultry Science, 2(4): $242-250$.

[4] AGBede, J. O. and ALETOR, V. A. (2004). Chemical characterization and protein quality evaluation of protein concentrates from Gliricidia sepium and Leucaenia leucocephala. International Journal of Food Science and Technology, 39(3): 253 $-261$.

[5] ChalotTe, M. B., TILley, D. R., and DELDAY, M. (2003). Determinant of meat quality: tenderness. Proceedings of Nutrition Society, 62: $337-347$

[6] DAMARIS, A. O. (2007). The potential of pigeonpea (Cajanus cajan (L.) Millsp) in Africa. Natural Resources Forum 31: 297 - 305.

[7] FOOD AND DRUG ADMINISTRATION (2012). CFSAN-Bad Bug Book-pH values of various foods. www.fda.gov.

[8] GILL, C. O., MCGINNIS, D. S., BRYANT, J. and CHABOT, B., (1995). Decontamination of commercial, polished pig carcasses with hot water. Food Microbiology 12, 143- 149.

[9] IHEUKWUMERE, F. C., NDUBUISI, E. C., MAZI, E. A. and ONYEKWERE, M. U. (2007). Growth, blood chemistry and carcass yield of broilers fed cassava leaf meal (Manihot esculenta crantz). International Journal of Poultry Science, 6(8): 555 559. 
[10] NRC (1994) Nutrient requirements of poultry; Ninth revised edition, 1994 Board on Agriculture. National Academy press, Washington, D. C

[11] PRZYBYLSKI, W. G., MONIN, M. and KOĆWINPODSIADLA, K. E. (2006). Glycogen metabolism in muscle and its effects on meat quality in pigs. $A$ mini review. Vol. 15/56 No 3. Pp $257-262$.

[12] Sarojini, T. R. (2005). Modern Biology $3^{\text {rd }}$ ed. Africana First Publisher Limited. Pp 295 - 313

Table.1: The Gross Composition ( $\mathrm{g} / \mathrm{kg}$ ) of the Weaner Diets

\begin{tabular}{lcccccc}
\hline INGREDIENTS & DIET I & DIET II & DIET III & DIET IV & DIET V & DIET VI \\
\hline Maize & 520.00 & 510.50 & 501.00 & 486.50 & 472.00 & 462.50 \\
Wheat offal & 20.00 & 20.00 & 20.00 & 20.00 & 20.00 & 20.00 \\
Soybean meal & 90.00 & 90.00 & 90.00 & 90.00 & 90.00 & 90.00 \\
Groundnut cake & 100.00 & 100.00 & 100.00 & 100.00 & 100.00 & 100.00 \\
Palm kernel cake & 90.00 & 90.00 & 90.00 & 90.00 & 90.00 & 90.00 \\
Brewer's dried grain & 150.00 & 150.00 & 150.00 & 150.00 & 150.00 & 150.00 \\
Bone meal & 15.00 & 15.00 & 15.00 & 15.00 & 15.00 & 15.00 \\
Oyster shell & 5.00 & 5.00 & 5.00 & 5.00 & 5.00 & 5.00 \\
Premix & 2.50 & 2.00 & 1.50 & 1.00 & 0.50 & 0.00 \\
Composite leaf meal & 0.00 & 10.00 & 20.00 & 30.00 & 40.00 & 50.00 \\
Salt & 2.50 & 2.50 & 2.50 & 2.50 & 2.50 & 2.50 \\
Vegetable oil & 5.00 & 5.00 & 5.00 & 10.00 & 15.00 & 15.00 \\
\hline Total & $\mathbf{1 0 0 0 . 0 0}$ & $\mathbf{1 0 0 0 . 0 0}$ & $\mathbf{1 0 0 0 . 0 0}$ & $\mathbf{1 0 0 0 . 0 0}$ & $\mathbf{1 0 0 0 . 0 0}$ & $\mathbf{1 0 0 0 . 0 0}$ \\
\hline Calculated & & & & & & \\
Crude Protein (g/kg) & 191.30 & 193.40 & 195.50 & 197.10 & 198.80 & 200.90 \\
Metabolizable energy (MJ/kg) & 11.87 & 11.74 & 11.60 & 11.58 & 11.56 & 11.42 \\
Lysine (g/kg) & 7.50 & 7.50 & 7.50 & 7.40 & 7.40 & 7.40 \\
\hline
\end{tabular}

Table.2: The Gross Composition ( $\mathrm{g} / \mathrm{kg}$ ) of the Grower Diets

\begin{tabular}{lcccccc}
\hline INGREDIENTS & DIET I & DIET II & DIET III & DIET IV & DIET V & DIET VI \\
\hline Maize & 560.00 & 550.50 & 541.00 & 526.50 & 512.00 & 502.50 \\
Wheat offal & 20.00 & 20.00 & 20.00 & 20.00 & 20.00 & 20.00 \\
Soybean meal & 65.00 & 65.00 & 65.00 & 65.00 & 65.00 & 65.00 \\
Groundnut cake & 100.00 & 100.00 & 100.00 & 100.00 & 100.00 & 100.00 \\
Palm kernel cake & 90.00 & 90.00 & 90.00 & 90.00 & 90.00 & 90.00 \\
Brewer's dried grain & 120.00 & 120.00 & 120.00 & 120.00 & 120.00 & 120.00 \\
Bone meal & 15.00 & 15.00 & 15.00 & 15.00 & 15.00 & 15.00 \\
Oyster shell & 5.00 & 5.00 & 5.00 & 5.00 & 5.00 & 5.00 \\
Premix & 2.50 & 2.00 & 1.50 & 1.00 & 0.50 & 0.00 \\
Composite leaf meal & 0.00 & 10.00 & 20.00 & 30.00 & 40.00 & 50.00 \\
Salt & 2.50 & 2.50 & 2.50 & 2.50 & 2.50 & 2.50 \\
Vegetable oil & 20.00 & 20.00 & 20.00 & 25.00 & 30.00 & 30.00 \\
\hline Total & $\mathbf{1 0 0 0 . 0 0}$ & $\mathbf{1 0 0 0 . 0 0}$ & $\mathbf{1 0 0 0 . 0 0}$ & $\mathbf{1 0 0 0 . 0 0}$ & $\mathbf{1 0 0 0 . 0 0}$ & $\mathbf{1 0 0 0 . 0 0}$ \\
\hline Calculated & & & & & & \\
Crude Protein (g/kg) & 176.80 & 178.80 & 180.90 & 182.60 & 184.20 & 186.30 \\
Metabolizable energy (MJ/kg) & 12.43 & 12.30 & 12.16 & 12.14 & 12.12 & 11.98 \\
Lysine (g/kg) & 6.70 & 6.60 & 6.60 & 6.60 & 6.50 & 6.50 \\
\hline
\end{tabular}




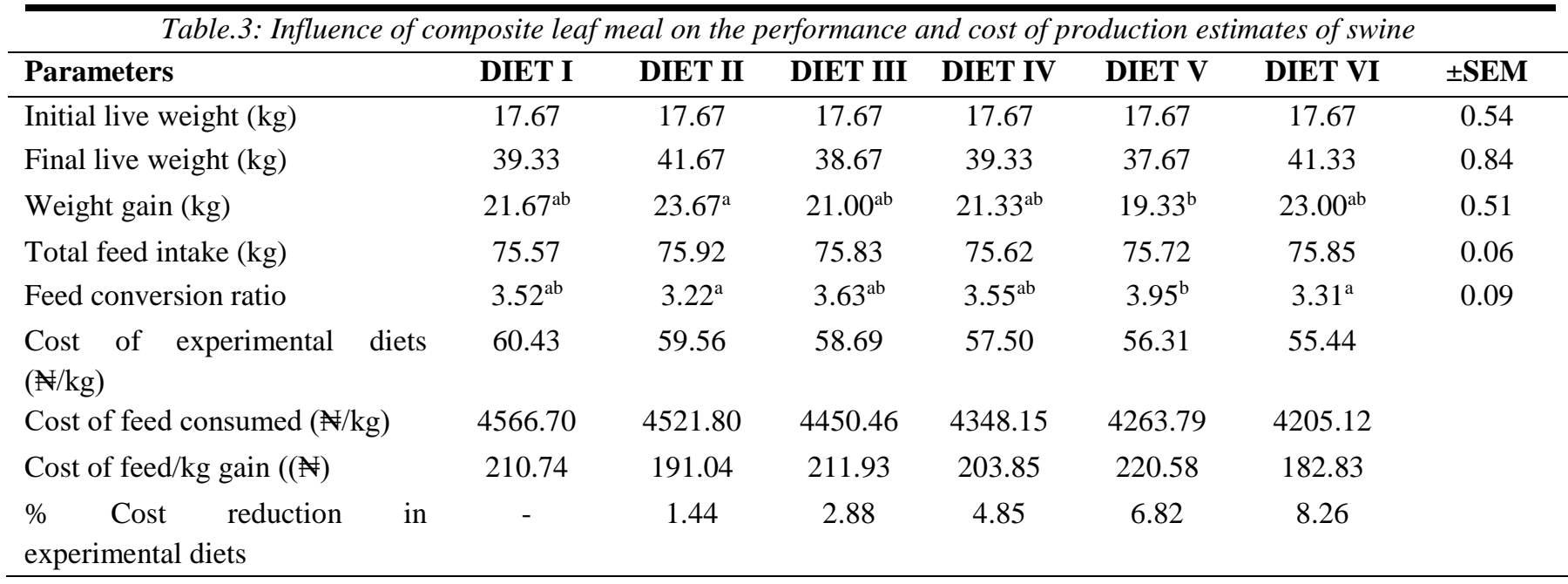
a-b: Mean within rows having different superscripts are significantly different $(\mathrm{P}<0.05)$

Table.4: Influence of composite leaf meal on the carcass and organs of swine

\begin{tabular}{|c|c|c|c|c|c|c|c|}
\hline Parameters & DIET I & DIET II & DIET III & DIET IV & DIET V & DIET VI & \pm SEM \\
\hline Live weight (kg) & 39.33 & 41.67 & 38.67 & 39.33 & 37.67 & 41.33 & 0.84 \\
\hline $\begin{array}{l}\text { Eviscerated weight } \\
(\mathrm{kg})\end{array}$ & 36.67 & 37.67 & 36.00 & 37.00 & 36.33 & 38.33 & 0.76 \\
\hline Head (kg) & 3.90 & 3.88 & 3.93 & 3.97 & 3.65 & 3.93 & 0.12 \\
\hline Carcass length $(\mathrm{cm})$ & 69.67 & 71.33 & 69.33 & 70.67 & 71.00 & 73.00 & 0.58 \\
\hline Liver $(\mathrm{g} / \mathrm{kg})$ & 779.33 & 904.00 & 800.33 & 881.33 & 922.00 & 956.00 & 28.95 \\
\hline Kidney $(\mathrm{g} / \mathrm{kg})$ & 132.33 & 133.67 & 114.67 & 118.67 & 127.33 & 118.33 & 3.09 \\
\hline Heart $(\mathrm{g} / / \mathrm{kg})$ & 153.67 & 129.33 & 134.67 & 123.00 & 143.00 & 135.00 & 4.35 \\
\hline Lungs $(\mathrm{g} / \mathrm{kg})$ & 311.33 & 310.33 & 315.67 & 374.33 & 315.33 & 334.67 & 9.76 \\
\hline Spleen $(\mathrm{g} / \mathrm{kg})$ & 54.00 & 55.67 & 57.67 & 63.33 & 58.67 & 52.33 & 2.08 \\
\hline
\end{tabular}

Table.5: Influence of composite leaf meal on the eye muscle and fat deposition of swine

\begin{tabular}{|c|c|c|c|c|c|c|c|}
\hline Parameters & DIET I & DIET II & DIET III & DIET IV & DIET V & DIET VI & \pm SEM \\
\hline $\begin{array}{l}\text { Eye muscle width }(\mathrm{cm}) \\
\text { (A) }\end{array}$ & $6.87^{\mathrm{a}}$ & $7.48^{\mathrm{b}}$ & $7.47^{\mathrm{b}}$ & $7.46^{\mathrm{b}}$ & $7.40^{\mathrm{b}}$ & $7.35^{\mathrm{b}}$ & 0.007 \\
\hline $\begin{array}{l}\text { Eye muscle depth }(\mathrm{cm}) \\
\text { (B) }\end{array}$ & 3.03 & 3.35 & 3.27 & 3.10 & 3.32 & 3.27 & 0.05 \\
\hline Shoulder fat $(\mathrm{cm})$ & 2.47 & 2.68 & 2.27 & 2.15 & 1.97 & 2.17 & 0.10 \\
\hline Midback fat $(\mathrm{cm})$ & $1.02^{\mathrm{ab}}$ & $1.23^{\mathrm{b}}$ & $0.83^{\mathrm{ab}}$ & $0.95^{\mathrm{ab}}$ & $0.77^{\mathrm{a}}$ & $0.85^{\mathrm{ab}}$ & 0.06 \\
\hline Loin fat (cm) & 0.93 & 1.25 & 0.72 & 0.82 & 0.80 & 0.82 & 0.09 \\
\hline $\mathrm{C}$ & 0.80 & 1.02 & 0.77 & 0.72 & 0.75 & 0.73 & 0.05 \\
\hline $\mathrm{K}$ & 0.92 & 1.28 & 0.75 & 0.63 & 0.63 & 0.72 & 0.09 \\
\hline $\mathrm{P}$ & 0.80 & 1.08 & 0.68 & 0.80 & 0.60 & 0.75 & 0.06 \\
\hline $\mathrm{pH}$ & 5.74 & 5.77 & 5.76 & 5.77 & 5.77 & 5.77 & 0.05 \\
\hline
\end{tabular}

a-b: Mean within rows having different superscripts are significantly different $(\mathrm{P}<0.05)$ 